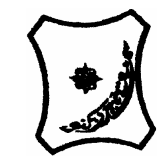

Bayero Journal of Pure and Applied Sciences, 9(2): 145 - 147

Received: April, 2016

Accepted: August, 2016

ISSN $2006-6996$

\title{
DETERMINATION OF AFLATOXIN CONTAMINATION IN CASSAVA FLOUR SOLD IN SELECTED MARKETS IN ZARIA, KADUNA STATE; NIGERIA
}

\author{
${ }^{1}$ Saleh, A., ${ }^{1}$ Abdullahi, I.O. and 1 Olonitola, 0. S. \\ 1 Department of Microbiology, Ahmadu Bello University, Zaria, \\ aliyurabadi@gmail.com (+2348024099140) \\ Kasuwan Magani, Marabar Kajuru, P.M.B. 01, Kajuru L.G., Kaduna State. \\ auwalkabuga76@gmail.com: 08068161470; +989306902127
}

\begin{abstract}
Cassava (Manihot esculenta) is a major staple food crop across tropical sub-Saharan Africa. Poor drying during processing or storage, especially during the rainy season, often results in contamination by fungi such as Aspergillus, Fusarium and Penicillium. Aflatoxins are among the mycotoxins which are secondary metabolites produced by some strains of Aspergillus flavus and Aspergillus parasiticus which are a major health concern to man and livestock because of their acute and chronic health effects. The aim of this study was to determine aflatoxin contamination and to quantify the aflatoxin levels in cassava flour. A total of 36 samples of Cassava flour were collected in three (3) major markets in Zaria, these are: Samaru, Sabon Gari and Zaria City Markets to determine and quantify aflatoxins using enzyme linked immunosorbent Assay (ELISA). The results obtained showed that 22 out of 36 were contaminated with total aflatoxins at the range of $2.0 \mu \mathrm{g} / \mathrm{kg}$ to $7.5 \mu \mathrm{g} / \mathrm{kg}$. This study indicated that there is low aflatoxin concentration in the Cassava and suggested that the cassava flour is safe and good for human consumption.
\end{abstract}

Key words: Cassava, Aflatoxin, Fungi, Market

\section{INTRODUCTION}

Cassava (Manihot esculenta ) is a major staple food crop across tropical sub-Saharan Africa (FAO, 2012). It has huge potential for industrial application in the plywood, confectionery, feed and pharmaceutical sectors (Moyo, et al. 2004; Kaaya and Eboku, 2010). However, poor drying during processing or storage, especially during the rainy season, often results in contamination by fungi such as Aspergillus, Fusarium and Penicillium that produce mycotoxins. Aflatoxins are among the mycotoxins which are secondary metabolites produced by some strains of Aspergillus flavus and Aspergillus parasiticus, aflatoxins and are a major health concern to man and livestock because of their acute and chronic health effects. Aflatoxins poses a greatest risk to health in tropical Africa because of their widespread prevalence and high toxicity (Manjula, et al. 2008) and have been known to be carcinogenic (cause liver and esophageal cancer), immune system suppressing and antinutritional contaminants in many food commodities and even to cause death (Jiang, 2005).

There are four naturally occurring aflatoxins, designated $B_{1}, B_{2}, G_{1}$ and $G_{2}$ with $A F B_{1}$ being the most common toxin (IARC, 1993). Aflatoxin B1 is produced by both Aspergillus flavus and Aspergillus parasiticus and aflatoxin $\mathrm{G}_{1}$ and $\mathrm{G}_{2}$ are produced exclusively by $A$. parasiticus. Aflatoxin $M_{1}$ and $M_{2}$ were originally discovered in the milk of cows that fed on moldy grains and also aflatoxins $M_{1}$ are metabolite of aflatoxin $B_{1}$ in humans and animals while aflatoxins $M_{2}$ are metabolite of aflatoxin $B_{2}$ in milk of cattle fed on contaminated foods (Boutrif, 1998).

\section{MATERIALS AND METHODS}

Sample Collection

A total of 36 samples of Cassava flour were randomly collected inside clean polythene bag at each point of sale in three (3) major markets in Zaria, these are: Samaru, Sabon Gari and Zaria City Markets and transported to the laboratory for the department of microbiology Ahmadu Bello University, Zaria for further analysis.

\section{Sample Processing and Preparation}

Fifty gram $(50 \mathrm{~g})$ of each sample (cassava flour) and $5.0 \mathrm{~g} \mathrm{NaCl}$ were transferred to a clean blender jar and $100 \mathrm{ml}$ of $80 \%$ methanol/water were added to the jar and blended for 1 minute in a high speed blender. The solution was filtered through a filter paper (coffee filter) and then $5 \mathrm{ml}$ of extract was diluted with $20 \mathrm{ml}$ of water, the mixture then were filtered through a glass fiber filter and the extracts were used for aflatoxin levels.

Determination of the Aflatoxin Levels in the Samples

The aflatoxin levels in the samples were determined using enzyme linked immunosorbent Assay (ELISA). According to the Beacon manufacturer's instruction aflatoxin test kit. Reagents and samples extracts were allowed to reach room temperature prior to starting the test. 
The appropriate numbers of test wells were placed into a microwell holder and $50 \mu$ l of enzyme conjugate were dispensing into each of the test well. Another $50 \mu l$ of calibrators and sample extracts were added to the appropriate test wells by using clean pipette tip

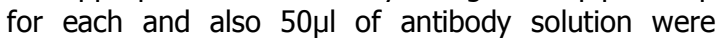
added into each test. The plate were gently shaken to mix the contents and incubated for 10 minutes. The contents of the wells were washed into an appropriate waste container by overflow to fill the wells with laboratory quality distilled water and were repeated 4 times for a total of five washes. Following the last washing the wash solutions were removed by inverting the wells onto absorbent paper and $100 \mu$ l of substrate was added into each well and shaken gently. Followed by incubation for 10 minutes, this was followed by addition of $10 \mu$ l of stop solution into each well and shaking the plate rack gently to mix. The absorbance of the wells were read at $450 \mathrm{~nm}$ using an ELISA reader and the printed results was interpreted quantitatively by graphing the absorbances of the calibrators (Y-axis, LOGI) versus the calibrator concentration (X-axis, LOG) on LOGLOGIT graph paper. A straight line was drawn through the calibrator points and the sample absorbance was located on the line. The corresponding point on the $\mathrm{Y}$-axis is the aflatoxins concentration $(\mu \mathrm{g} / \mathrm{kg})$ of the sample.

\section{RESULTS}

Aflatoxin concentration in flour from Samaru Market indicated 8 out of 12 Cassava were contaminated with the total aflatoxin $2.0 \mu \mathrm{g} / \mathrm{kg}$ to $7.5 \mu \mathrm{g} / \mathrm{kg}$ and also a total aflatoxin concentration in flour from Sabon gari Market, 3 out of 12 Cassava flour were contaminated with $2.0 \mu \mathrm{g} / \mathrm{kg}$ respectively (Table 1 ).

However, the total aflatoxin concentration in sample from Zaria city Market revealed 11 out of 12 Cassava flour were contaminated with $2.0 \mu \mathrm{g} / \mathrm{kg}$ to $7.5 \mu \mathrm{g} / \mathrm{kg}$ as shown in Table 1.

The statistical package for social sciences (IBM SPSS statistics21) was used for the analysis of variance of mean of aflatoxin concentration of all the three markets, Samaru 1.80, Sabon gari 0.50 and zaria city 3.21 as presented in table 2. Statistically between Zaria-Samaru $(p=0.009)$ and Zaria-Sabo $(p=0.002)$ are significant while between Samaru-Sabo markets are not significant $(p=0.123)$ (Table 2$)$.

Table 1: Comparison for Aflatoxin Concentration in Cassava Flours from Three Markets

\begin{tabular}{cccc}
\hline SAMPLE & $\begin{array}{c}\text { SAMARU } \\
\text { AFLATOXIN }(\boldsymbol{\mu g} / \mathbf{k g})\end{array}$ & $\begin{array}{c}\text { SABON GARI } \\
\text { AFLATOXIN }(\boldsymbol{\mu g} / \mathbf{k g})\end{array}$ & $\begin{array}{c}\text { ZARIA } \\
\text { AFLATOXIN }(\boldsymbol{\mu g} / \mathbf{k g})\end{array}$ \\
\hline A & 2.0 & 0.0 & 2.0 \\
B & 0.0 & 0.0 & 0.0 \\
C & 0.0 & 0.0 & 2.0 \\
D & 0.0 & 0.0 & 7.5 \\
E & 2.0 & 2.0 & 2.0 \\
F & 2.0 & 2.0 & 2.0 \\
G & 7.5 & 0.0 & 2.0 \\
H & 2.0 & 2.0 & 2.0 \\
I & 2.0 & 0.0 & 2.0 \\
J & 2.0 & 0.0 & 7.5 \\
K & 2.0 & 0.0 & 7.5 \\
L & 0.0 & 0.0 & 3.21 \\
\hline
\end{tabular}

Table 2: Analysis of Variance of Mean of Aflatoxin Concentration from the Three Markets

\begin{tabular}{lcc}
\hline MARKETS & $\begin{array}{c}\text { MEAN OF AFLATOXIN } \\
(\boldsymbol{\mu g} / \mathbf{k g})\end{array}$ & P-VALUE \\
\hline SAMARU- SABO & $1.80-0.50$ & $\mathbf{0 . 1 2 3}$ \\
ZARIA-SAMARU & $3.21-1.80$ & $\mathbf{0 . 0 0 9}$ \\
ZARIA- SABO & $3.21-0.50$ & $\mathbf{0 . 0 0 2}$ \\
\hline
\end{tabular}

$P \leq 0.05$

\section{DISCUSSION}

Aflatoxins in the agricultural produce could not be avoided completely but would be reduce to acceptable limits. There is no safe level for aflatoxin for human consunption but most of the countries including Nigeria taking into account global standard to regulate aflatoxin levels in all food at 20ppb (FAO, 1997). The regulation is because to reduce the chance of occurrence of serious health related hazard due to the ingestion of high level of aflatoxins in food such as hepatocellular carcinoma (HCC- Liver cancer) (Liu and $\mathrm{Wu}, 2010$. A total of 36 samples of Cassava flour were tested for total aflatoxin concentration. This study revealed that the aflatoxin contamination in cassava flour ranged from $2.0 \mu \mathrm{g} / \mathrm{kg}$ to $7.5 \mu \mathrm{g} / \mathrm{kg}$. These was below the maximum acceptable limited of $10 \mu \mathrm{g} / \mathrm{kg}$ stated by Codex Alimentarus Commission, (1995) of the UN and suggested by NAFDAC in Nigeria (Atanda, 2005). This result is in agreement with that reported by Chiona, et al. (2014) at Malawi and Zambia the level of fungal and mycotoxins contamination in commonly processed Cassava products. It also agrees with Bankole, et al. (2006) who reported that Cassava and Yam are not vulnerable to aflatoxin contamination. 
However, this result showed that 14 out of 36 samples were not contaminated with aflatoxins while those contaminated had less than $10 \mu \mathrm{g} / \mathrm{kg}$. This is may be due the fact that Cassava flour does not provide a good substrate for aflatoxin production (Wood, 1992) and however, the analysis of variance of mean of aflatoxin concentration of all the three markets revealed that statistically between ZariaSamaru $(p=0.009)$ and Zaria-Sabo $(p=0.000)$ are significant while between Samaru-Sabo markets are not significant $(p=0.123)$, this may be due to the fact that difference in storage techniques and ecological conditions as supported by Roy and Chourasia (1990).

\section{CONCLUSION}

This study revealed that there is low aflatoxin concentration in the Cassava flour from the study area which suggested that the cassava flour is safe and good for human consumption.

\section{REFERENCES}

Atanda, O.O. (2005). Development of a diagnostic medium for direct determination of aflatoxin and its control using traditional spices, Ph.D Thesis. University of Agriculture, Department of Microbiology, Abeokuta, Nigeria.

Bankole, S.A., Ogunsanwo, B.M., Osho, A. and Adewuyi, G.A. (2006). Fungal contamination and aflatoxin B1 of egusi_melon seeds in Nigeria. Food Contro/ 17: 814-818.

Boutrif, E. (1998). "Prevention of Aflatoxin in Pistachios". Food, Nutrition and Agriculture. 2:1

Chiona, M., Ntawuruhunga, P. Benesi, I.RM., Matumba, L. and Moyo, C.C. (2014). Aflatoxins contamination in processed cassava in Malawi and Zambia. african journal of food and Agricultural nutrition and Development, 14:3: 8809-8820.

Codex Alimentarius Commission (1995). Codex general Standard for contamination toxins in food and feed (CODEX STAN 193-1995).

Food and Agricutltural Organization (1997). Agriculture food and nutrition for Africa: A resource book for teachers of agriculture.

FAO. FAOSTAT. (http://faostat.fao.org/). 2012. Accessed on 10th December 2012.

Gong, Y.Y., Hounsa, A., Egal, S., Turner, P.C., Sutcliffe, A.E., Hall, A.J., Cardwell, K.F. and Wild, C.P. (2004). Post-weaning exposure to aflatoxin results in impaired child growth: $A$ Longitudinal study in Benin, West Africa. Environmental Health Perspective; 112: 1334-1338.

International Agency for Research in Cancer [IARC]. (1993). Some Naturally Occurring Substances: Food Items and Constituents. IARC Monographs on Evaluation of Carcinogenic risk to human, $\mathbf{5 6 .}$

\section{CONTRIBUTIONS OF AUTHORS}

Based on the findings my contributions are:

These findings revealed that the cassava flour are safe for human consumption as at that period of the study and also this finding will be use for future literature and serve as an avenue for further research due to the fact that there is little or no available record related to presence of aflatoxins in cassava flour in the study area.

\section{CONFLICT OF INTEREST}

The conflict of interest is none

\section{ACKNOWLEDGEMENT}

My profound gratitude goes to co-authors for their support, efforts and contributions throughout the period of the research and my parents.

Jiang, Y., Jolly, P.E., Ellis, W.O., Wang, J.S., Phillips, T.D. and Williams J.H. (2005). Aflatoxin B1 albumin adduct levels and cellular immune status in Ghanaians. International Journal of Immunology, 17(6): 807-814.

Kaaya, A.N. and Eboku, D. (2010). Mould and Aflatoxin Contamination of Dried Cassava Chips in Eastern Uganda: Association with Traditional Processing and Storag Practices. Journal of Biological Science; 10: 718-729.

Liu, Y. and Wu, F. (2010). Global Burden of Aflatoxin - Induced Hepato Cellular

Carcinoma: A Risk Assessment. Environmental Health Perspectives, 118(6)818- 824.

Manjula, K., Hell, K., Fandohan, P., Abass, A. and Bandyopadhyay, R. (2008). Aflatoxin and fumonisin contamination of cassava products and maize grain from markets in Tanzania and Republic of the Congo. Informa Healthcare.

Moyo C.C, Mahungu N.M, Sandifolo V.S, Jumbo S., Mhone A. and Mangirani, P. T. (2004). Investigations into cassava stem storage and its effects on sprouting and growth. Proceedings of the 9th ISTRC-AB Symposium, Kenya.

Roy, A.K. and Chourasia, H.K. (1990). Mycoflora, Mycotoxin productibility and mycotoxins in traditional herbal drugs from India. Journal of General Applied Microbiology. 36:295302.

Wood, J.F. (1992). Quality aspects of tradable cassava products including problems of adulteration. In: Roots, Tubers, Plantain and Bananas in animal feedings. Machin Dand S. Nyrold (Eds) FAO Animal production and Health Paper 95:67-80. 